\title{
PENGARUH PELATIHAN PERENCANAAN KARIR UNTUK MENINGKATKAN EFIKASI DIRI TERHADAP PILIHAN BIDANG MINAT KARIR PSIKOLOGI PADA MAHASISWA PSIKOLOGI UNESA
}

\author{
Olievia Prabandini Mulyana dan Ni Wayan Sukmawati Puspitadewi \\ Program Studi Psikologi Universitas Negeri Surabaya
}

\begin{abstract}
This research is aimed to determine the effectivity of training to increase selfefficacy towards career preference options in psychology. This is a quantitative research, in which experiment method is applied by using pretest-posttest control group design. The dependent variable is self-efficacy towards career preference options in psychology. Self efficacy towards career preference options in psychology is measured using self efficacy towards career preference options scale. The independent variable in this research is career planning training. The research subject are 40 persons groupped into experiment group and control group. Pre-test are given to both experiment and control group. next, the experiment group is given treatment of career planning training. The next step, post test is administered to experiment group and control group. The research is analized using anava repeated measure. Anava repeated measure resulted showing significant result. Thus, hyphothesis stating that there is effect of career planning training to self efficacy towards career preference options for psychology student of UNESA is accepted. Self efficacy towards career preference options for psychology increased after career planning training is given as treatment. Self efficacy towards career preference options for psychology in experiment group between pre-test and post-test is differents.
\end{abstract}

Keywords: self efficacy, career preference options for psychology, career planning.

\begin{abstract}
Abstrak: Penelitian ini bertujuan untuk mengetahui efektivitas pelatihan dalam meningkatkan efikasi diri terhadap pilihan bidang minat karir psikologi. Jenis penelitian yang digunakan dalam penelitian ini adalah penelitian kuantitatif. Penelitian ini menggunakan metode eksperimen dengan desain eksperimen yang digunakan adalah pretest-posttest control group design. Variabel tergantung pada penelitian ini adalah efikasi diri terhadap pilihan bidang minat karir psikologi. Kemampuan efikasi diri terhadap pilihan bidang minat karir psikologi diukur dengan skala efikasi diri terhadap pilihan bidang minat karir. Sedangkan variabel bebas dalam penelitian ini adalah pelatihan perencanaan karir. Subjek penelitian yang berjumlah 40 orang yang kemudian dikelompokkan ke dalam kelompok eksperimen dan kelompok kontrol. Pada kelompok eksperimen dan kelompok kontrol diberikan pre-test. Selanjutnya pada kelompok eksperimen dikenai perlakuan berupa pelatihan perencanaan karir. Tahapan berikutnya adalah pemberian posttest pada kelompok eksprimen dan kelompok kontrol. Analisis yang akan digunakan adalah anava amatan ulangan. Hasil anava amatan ulangan menunjukkan hasil yang signifikan. Dengan demikian, hipotesis yang menyatakan bahwa ada pengaruh pelatihan perencanaan karir terhadap efikasi diri terkait pilihan minat bidang karir psikologi pada mahasiswa psikologi UNESA, diterima. Efikasi diri terhadap pilihan minat bidang karir di Psikologi meningkat setelah diberikan pelatihan perencanaan karir.
\end{abstract}

Kata kunci : Efikasi diri, pilihan minat psikologi, pelatihan perencanaan karir 
Individu memiliki tugas-tugas perkembangan yang harus dipenuhi untuk menuju pada tahapan perkembangan berikutnya. Salah satu tugas perkembangan pada masa dewasa adalah menghadapi dunia kerja dan karir. Karir merupakan urutan-urutan aktivitas yang berhubungan dengan pekerjaan dan perilaku, nilai-nilai serta aspirasi individu selama rentang hidup individu tersebut (Simamora, 2004).

Menurut Hurlock (1996) masa untuk menghadapi dunia kerja biasa disebut dengan masa mengharapkan kerja atau masa job hopping dan berlangsung pada saat individu berusia sekitar 20 tahun. Pada kondisi tersebut individu akan dihadapkan pada pilihanpilihan yang berkaitan dengan karirnya antara lain pilihan untuk bekerja atau meneruskan jenjang pendidikan yang lebih tinggi, pilihan untuk mencari suatu pekerjaan berdasarkan bidang kerja, jenis organisasi, gaji dll. Pilihanpilihan tersebut akan menuntut individu untuk mengambil keputusan-keputusan yang berkaitan dengan pekerjaaan atau karir.

Teori perkembangan karir oleh Super terdiri dari beberapa tahapan perkembangan yaitu : Usia 14-18 tahun, pada fase ini disebut kristalisasi yaitu individu sebagai remaja mengembangkan gagasan tentang bekerja yang berhubungan dengan konsep diri secara global. Usia 18-22 tahun, pada fase ini disebut fase pengkhususan yaitu individu mempersempit pemilihan karir dan memulai perilaku yang memungkinkan mereka memasuki beberapa tipe karir. Usia 21-24 tahun, pada fase ini disebut implementasi yaitu individu sebagai orang dewasa muda menyelesaikan pendidikan dan pelatihan serta mulai memasuki dunia kerja. Usia 25-35 tahun, pada fase ini disebut stabilasi yaitu keputusan untuk memilih dan cocok dengan karir tertentu. Usia diatas 35 tahun, pada fase ini disebut konsolidasi yaitu individu berusaha memajukan karir dan mencapai posisi yang statusnya lebih tinggi (dalam Santrock, 2002).

Pada usia 18-22 tahun, individu pada umumnya berada pada jenjang pendidikan di
Perguruan Tinggi sehingga dapat juga disebut dengan mahasiswa. Mahasiswa memiliki tugas perkembangan mempersiapkan diri menghadapi dunia kerja. Persiapan untuk menghadapi dunia kerja bisa dilakukan dengan cara memperoleh gambaran yang jelas mengenai pekerjaan yang akan ditekuninya, ketrampilan dan kemampuan yang dibutuhkan supaya dapat melakukan pekerjaan dengan baik, serta karakteristik kepribadian yang cocok dengan pekerjaan (Sukardi, 1993). Pada fase ini juga individu mempersempit pemilihan karir dan memulai perilaku yang memungkinkan mereka memasuki beberapa tipe karir. Hal tersebut juga berlaku bagi mahasiswa psikologi.

Ilmu psikologi secara garis besar dapat dibagi menjadi empat bidang minat karir, yaitu psikologi klinis, psikologi industri dan organisasi dan psikologi pendidikan dan psikologi sosial. Setiap bidang minat karir mendalami ilmu psikologi tertentu yang sifatnya spesifik. Pada semester awal mahasiswa diberikan materi psikologi yang sifatnya masih umum dan pada semester selanjutnya mahasiswa diminta untuk mendalami suatu bidang minat karir tertentu yang dianggap paling cocok dengan minat.

Mahasiswa harus dapat menentukan pilihan minat bidang karir psikologi yang sesuai dengan dirinya sekaligus memiliki keyakinan atas pilihan karir di bidang minat psikologi yang dipilihnya baik dalam minat psikologi klinis, psikologi industri dan organisasi dan psikologi pendidikan dan psikologi sosial. Dengan demikian, mahasiswa tersebut dapat lebih terarah dalam melaksanakan tugas belajarnya dengan memilih mata kuliah pilihan yang sesuai, memilih bidang minat pada praktek kerja lapangan (PKL), dan memilih judul skripsi yang sesuai dengan bidang yang dipilih serta mengikuti kegiatan-kegiatan tambahan yang cocok dengan bidang pekerjaan yang dipilihnya.

Secara umum banyak mahasiswa yang mengalami kebingungan saat diminta 
untuk menentukan bidang minat karir yang akan ditekuni, tidak terkecuali mahasiswa psikologi. Mahasiswa psikologi UNESA juga mengalami kesulitan dalam mencapai kristalisasi pilihan bidang minat karir, sehingga mengalami kesulitan untuk mendalami bidang minat karir tertentu. Sebaliknya, mahasiswa yang sudah memiliki keyakinan terhadap pilihan bidang minat karir akan lebih terarah karirnya.

Keyakinan seseorang terhadap kemampuan yang dimilikinya disebut dengan efikasi diri. Efikasi diri berhubungan dengan kepercayaan diri seseorang, bahkan efikasi diri sering juga disebut dengan self confidence. Kepercayaan diri atau self confidence adalah sejauhmana seseorang memliki keyakinan terhadap penilaian atas kemampuan dirinya dan sejauhmana seseorang dapat merasakan adanya "kepantasan" untuk berhasil. Kepercayaan terhadap kemampuan diri diperoleh setelah diri kita berinteraksi dengan orang lain dan mendapatkan umpan balik (Bandura, 1997). Konsep efikasi diri dikembangkan oleh Bandura berdasarkan teori belajar social (social learning theory) yang menekankan hubungan kausal timbal balik (reciprocal determinism) antara faktor lingkungan perilaku dan faktor personal yang saling berkaitan.

Efikasi diri menjadi hal penting karena efikasi diri merefleksikan kepercayaan seseorang bahwa orang tersebut mampu mengatasi permasalahan yang sedang dihadapi. Konsep dari efikasi individu berasal dari teori Bandura dapat diaplikasikan dalam domain karir yang spesifik dan tidak bersifat umum sehingga konsep ini harus mengacu pada perilaku tertentu agar bermakna. misal: pada tugastugas jabatan karir, manajemen peran yang beragam, dan perilaku individu dalam ekplorasi karir (Betz \& Luzzo, 1996), efikasi diri terhadap pengambilan keputusan karir (Hackett dalam Gainor, 2006).Efikasi diri terhadap pilihan bidang minat karir psikologi adalah suatu tingkat perkembangan karir dimana individu telah mempunyai tingkat kejelasan pilihan bidang minat karir berdasarkan berbagai macam pertimbangan serta mau berkomitmen untuk mencapai pilihan karirnya.

\section{METODE}

\section{Populasi}

Populasi pada penelitian ini adalah mahasiswa program S-1 Psikologi UNESA angkatan 2013 yang berjumlah 83 orang. Pemilihan angkatan 2013 dikarenakan mahasiswa tersebut sudah menempuh 4 (empat) semester sehingga sudah memiliki keyakinan untuk kuliah di Psikologi. Selain itu, dasar-dasar ilmu psikologi pendidikan, perkembangan, industri dan organisasi, klinis, sosial mulai diajarkan pada semester 3 sehingga mahasiswa angkatan 2013 sudah mengenal minat bidang karir di Psikologi sekaligus mempersiapkan untuk memilih bidang minat psikologi pendidikan, perkembangan, industri dan organisasi, klinis ataupun sosial pada Praktek Kerja Lapangan.

\section{Sampel}

Pemilihan sampel dilakukan dengan teknik purposive sampling, yaitu sampel di ambil sesuai dengan kriteria yang telah ditetapkan yaitu mahasiswa angkatan 2013 pada program S-1 Psikologi UNESA. Sampel pada penelitian ini sejumlah 40 orang sedangkan 43 orang lainnya digunakan untuk uji coba alat ukur yang berupa skala efikasi diri terhadap pilihan bidang minat karir di psikologi. 40 orang tersebut secara acak akan dipilih 20 orang untuk kelompok ekperimen dan 20 orang untuk kelompok kontrol.

\section{Rancangan Penelitian}

Jenis penelitian yang digunakan dalam penelitian ini adalah penelitian kuantitatif. Penelitian ini menggunakan metode eksperimen. Subjek penelitian dikelompokkan ke dalam kelompok eksperimen dan kontrol secara acak. Pada 
kelompok eksperimen dan kelompok kontrol diberikan pretest. Selanjutnya pada kelompok eksperimen dikenai perlakuan berupa pelatihan perencanaan karir. Tahapan berikutnya adalah pemberian posttest pada kelompok eksprimen dan kelompok kontrol. Berdasarkan uraian pelaksanaan penelitian yang dilakukan dalam penelitian ini, maka desain ekpserimen yang digunakan adalah pretest-posttest control group design.

Desain ekpserimen pretest-posttest control group design yaitu desain eksperimen yang membutuhkan dua kondisi perlakuan dengan menggunakan dua kelompok subjek yang ditempatkan melalui random assignment (Mayers dan Hansen, 2002).

$\begin{array}{cccc}\mathrm{R}(\mathrm{KE}) & \mathrm{O} 1 \quad \square & \mathrm{X} & \square \mathrm{O} 2 \\ \mathrm{R}(\mathrm{KK}) & \mathrm{O} 1{ }^{\prime} & - & \square \mathrm{O} 2\end{array}$

Gambar 1. Rancangan Eksperimen

$$
\begin{aligned}
& \text { Keterangan : } \\
& \text { R (KE) : Random (Kelompok Eksperimen) } \\
& \text { R (KK) : Random (Kelompok Kontrol) }
\end{aligned}
$$

\section{Teknik Pengumpulan Data}

Untuk mengetahui tingkat efikasi diri terhadap pilihan bidang minat karir psikologi digunakan skala efikasi diri terhadap pilihan bidang minat karir psikologi yang merupakan modifikasi dari skala efikasi diri terhadap karir versi Taylor dan Betz's. Skala efikasi diri terhadap pilihan bidang minat psikologi yang mengacu pada teori Crites mengenai kematangan karir (Betz, Klien, \& Taylor, 1996).

Skala ini terdiri dari 50 aitem yang meliputi lima aspek skala efikasi diri terhadap pilihan bidang minat psikologi, yaitu membuat penilaian diri dengan tepat, mengumpulkan informasi mengenai bidang minat karir di psikologi, menyeleksi bidang minat karir yang sesuai, membuat renacanrencana karir sesuai dengan pilihan bidang minat karir, dan menyelesaikan permasalahan yang berkaitan dengan pilihan terhadap bidang minat karir di Psikologi. Skor total dari skala efikasi diri terhadap pilihan bidang minat psikologi menunjukkan bahwa semakin tinggi skor yang diperoleh individu maka semakin tinggi efikasi diri terhadap pilihan bidang minat psikologi. Sebaliknya rendah skor diperoleh, maka semakin rendah efikasi diri terhadap pilihan bidang minat psikologi.

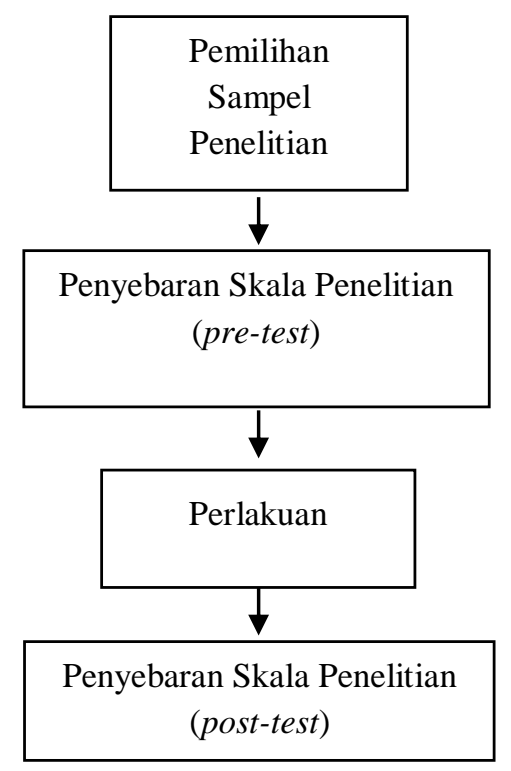

Gambar 2. Prosedur Penelitian

\section{Teknik Analisis Data}

Penelitan ini menggunakan analisis anava amatan ulangan untuk melihat ada tidaknya perbedaan pre-test dan post-test pada kelompok eksperimen dan kelompok kontrol.

\section{HASIL DAN PEMBAHASAN}

Penelitian ini menggunakan model penelitian pretest-posttest control group design yaitu penelitian eksperimen yang membutuhkan dua kondisi perlakuan dengan menempatkan subjek penelitian dalam dua kelompok, yaitu kelompok eksperimen dan 
kelompok kontrol (Mayers dan Hansen, 2002). Kelompok eksperimen akan dikenai perlakukan berupa pelatihan perencanaan karir sedangkan kelompok lainnya tidak dikenai perlakukan apapun karena berfungsi sebagai kelompok kontrol. Setiap subjek penelitian baik pada kelompok eksperimen dan kelompok kontrol akan dikenai pre-test dan post-test yang berupa skala efikasi diri terhadap pilihan bidang minat karir psikologi. Hasil pre-test dan post-test pada seluruh subjek penelitian akan dianalisis menggunakan anava amatan ulangan.

Hasil analisis data dengan anava amatan ulangan menunjukkan bahwa terdapat peningkatan efikasi diri terhadap pilihan bidang minat psikologi melalui pelatihan perencanaan karir $(\mathrm{p}<0,05)$. Kelompok eksperimen menunjukkan peningkatan efikasi diri terhadap pilihan bidang minat karir psikologi setelah diberi perlakuan pelatihan perencanaan karir. Hasil analisis tersebut ditunjang dengan analisis uji $\mathrm{t}$ yaitu paired samples $t$ test $(\mathrm{p}<0,05)$ yang menunjukkan bahwa ada perbedaan efikasi diri pengambilan keputusan karir yang signifikan pada kelompok eksperimen antara pre-test dan post-test $(\mathrm{p}<0,05)$.

Analisis untuk sumbangan efektif didapatkan melalui eta kuadrat yaitu berapa persen prosentasi variasi variabel dependen yang diakibatkan oleh perlakuan. Pada penelitian ini menunjukkan pengaruh pelatihan efikasi terhadap keputusan karir mampu meningkatkan efikasi diri terhadap pilihan bidang minat psikologi sebesar $45 \%$.

Goldsmith dan Kraiger menyatakan bahwa pelatihan adalah suatu metode yang digunakan untuk menambah keahlian peserta dalam domain yang spesifik (dalam Salas \& Bower, 2001). Ball (1997) menyatakan bahwa manfaat perencanaan karir yaitu membuat individu semakin merasa yakin terhadap diri dan masa depannya; melibatkan sebuah proses kreatif karena mampu membuka wawasan seseorang tentang berbagai macam pilihan karir yang tersedia; perencanaan karir menempatkan sasaran-sasaran bagi perkembangan pribadi dan karir, untuk pekerjaan dan kehidupan secara menyeluruh; membuat seseorang mampu mengendalikan dan merencanakan masa depannya; memperbesar kemungkinan keberhasilan proses pencapaian tujuan karir karena seseorang terlibat secara langsung proses pembuatan keputusan karir.

Pada penelitian ini, pelatihan meningkatkan kemampuan dan keahlian peserta pada domian karir yang spesifik yaitu efikasi diri terhadap pilihan bidang minat psikologi. Pelatihan perencanaan karir akan meningkatkan pengetahuan dan pemahaman individu mengenai pilihan bidang minat karir di psikologi yang terdiri dari psikologi pendidikan, psikologi perkembangan, psikologi klinis, psikologi sosial serta psikologi industri dan organisasi. Peningkatan efikasi diri terhadap pilihan bidang minat psikologi akan terjadi ketika individu menerapkan materi-materi dan metode yang didapatkan pada pelatihan ke dalam perkuliahan termasuk memilih mata kuliah pilihan, menentukan bidang pilihan psikologi pada praktek kerja lapangan (PKL) serta memilih judul yang sesuai pada skripsi yang dikerjakannya. Hal ini sesuai dengan penelitian yang dilakukan oleh Mitchell (dalam Greenberg, 2000) yang menunjukkan efikasi diri melibatkan proses kognisi yang cukup besar sebelum individu sampai pada kesimpulan yang benar.

Konsep ekspektasi efikasi diri sangat bermanfaat untuk memahami dan memodifikasi perilaku karir termasuk terhadap pilihan bidang minat psikologi. Individu dengan efikasi diri yang tinggi dalam menentukan pilihan bidang minat karir akan memiliki keyakinan diri bahwa ia dapat membuat penilaian diri dengan tepat yaitu mengetahui kelebihan dan kelemahan dirinya; mampu mengumpulkan informasi-informasi yang berhubungan dengan pekerjaan; dapat memilih suatu tujuan karir yang tepat berdasarkan informasi- informasi yang dapat diolah dengan baik, mampu membuat suatu 
perencanaan karir yang tepat dan disesuaikan dengan tujuan karirnya baik jangka pendek maupun jangka panjang; serta dengan bijaksana dapat memecahkan permasalahpermasalahan yang berkaitan dengan pencapaian karirnya.

Pelatihan perencanaan karir akan membuka wawasan individu mengenai pilihan bidang minat di psikologi dan menfokuskan individu untuk membuat tujuan karir yang sesuai. Hal ini sesuai dengan pendapat Robbins (2001) yang menyatakan bahwa efikasi diri akan muncul jika seseorang memiliki orientasi tujuan. Jika dikaitkan dengan teori motivasi, maka orientasi tujuan yang tinggi akan muncul jika seseorang memiliki keinginan untuk mencapai tingkat kebutuhan yang lebih tinggi. Dikatakan pula bahwa semakin tinggi efikasi seseorang maka semakin besar kepercayaan diri terhadap kemampuannya untuk berhasil dalam suatu tugas. Penelitian Bell dan Kozlowski (2002) membuktikan bahwa individu yang memiliki kemampuan kognitif yang tinggi akan mampu mengadaptasi orientasi tujuan sehingga dapat meningkatkan efikasi dirinya, sedangkan individu yang memiliki kemampuan kognitif yang rendah kurang mampu mengadaptasi orientasi tujuan sehingga menghambat efikasi dirinya.

Berdasarkan hasil evaluasi pelaksanaan pelatihan menyatakan bahwa para peserta mendapatkan manfaat mengenai karir mereka. Sebagian peserta sudah dapat memetakan kelebihan dirinya dan meningkatkan kemampuannya untuk mengatasi kekurangan yang terjadi pada dirinya. Mereka juga memiliki keyakinan untuk mendapatkan pilihan bidang karir di psikologi yang sesuai dengan minat dan latar belakang mereka. Selain itu, dengan kemampuan yang bertambah mengenai pilihan-pilihan karir di psikologi, mereka lebih yakin untuk mengatasi permasalahanpermasalahan karir dan mengambil keputusan karir termasuk kemungkinan untuk kesiapan untuk perubahan-perubahan orientasi karir di masa depan. Hal tersebut menunjukkan bahwa dalam meningkatkan efikasi diri terhadap pilihan bidang minat psikologi, para peserta tidak hanya belajar pada saat proses pelaksanaan penelitian namun terus berkelanjutan mempelajari materi-materi dan metode-metode dalam pelatihan perencanaan karir dan menerapkan pada pekerjaan dan manajeman karirnya. Keberhasilan peningkatan efikasi diri terhadap pilihan bidang minat psikologi pada setiap individu dapat bervariasi dipengaruhi oleh pengetahun, pemahaman dan penerapan pelatihan perencanaan karir dalam pekerjaan dan manajeman karir masing-masing individu.

\section{SIMPULAN}

Berdasarkan hasil analisis data dan pembahasan hasil penelitian, maka dapat ditarik kesimpulan bahwa pelatihan perencanaan karir dapat meningkatkan efikasi diri terhadap pilihan bidang minat karir psikologi. Hal ini ditunjukkan dengan adanya perbedaan efikasi diri terhadap pilihan bidang minat karir psikologi antara sebelum dan sesudah dilakukan pelatihan perencanaan karir. Kelompok eksperimen menunjukkan peningkatan efikasi diri terhadap pilihan bidang minat karir psikologi setelah diberi perlakuan pelatihan perencanaan karir.

\section{Daftar Pustaka}

Ball, B. (1997). Assessing Your Career : Time for Change. Yogyakarta : Kanisius.

Bandura, A. (1997). Self Efficacy: The Exercise of Control. New York: Freeman.
Bell, B.S., \& Kozlowski, S.W.J. (2002). Goal Orientation and Ability: Interactive Effect on Self-Efficacy, Performance and Knowledge, Journal of Applied

Betz, N. E., \& Luzzo, D. A. (1996). Career 
Assessment and the Career DecisionMaking Self-Efficacy Scale. Journal of Career Assessment, 4, 413-428.

Betz, N. E., Klien, K. L., \& Taylor, K. M. (1996). Evaluation of a Short Form of the Career Decision-Making SelfEfficacy Scale. Journal of Career Assessment, 4, 47-57.

Gainor, K. A. (2006). Twenty-Five Years of Self-Efficacy In Career Assessment And Practice. Journal of Career Assessment, 14, 161-175.

Greenberg, J., \& Baron, R.A. (2000). Behavior in Organizations. 7 editions. New Jersey: Prentice Hall International Edition.

Hurlock, E.B. (1996). Psikologi Perkembangan. Suatu Pendekatan Sepanjang
Rentang Kehidupan (terjemahan), Surabaya : PT Erlangga.

Robbins, S.P. (2001).Organizational Behaviour: Concept, Controversies and Applications. Edisi Bahasa Indonesia, Jilid I \& 2, Jakarta: PT Prenhallindo.

Salas, E \& Bowers, C.J.A. (2001). The Science of Training : A Decade of Pregress, Annual Review Psychology, Vol 52. 471-499.

Santrock, J. W. (2012). Life-Span Development. Jakarta : PT Erlangga.

Simamora, H. (2004). Manajemen Sumber Daya Manusia. Yogyakarta : STIE YKPN.

Sukardi, D.K. (1993). Psikologi Pemilihan Karir. Jakarta : PT Rinneka Cipta. 